\title{
Naloxone-reversible effects of ethanol on passive avoidance behavior in mice
}

\author{
CLAUDIO CASTELLANO and FLAMINIA PAVONE \\ Istituto di Psicobiologia e Psicofarmacologia del CNR, Rome, Italy
}

\begin{abstract}
Performance impairments were evident, in CD1 mice tested in a passive avoidance apparatus, following posttrial intraperitoneal administration of ethanol $(1.0$ and $2.0 \mathrm{~g} / \mathrm{kg})$ or morphine $(0.5$ and $1.0 \mathrm{mg} / \mathrm{kg}$ ), or following posttrial immobilization stress (30 and $60 \mathrm{~min}$ ). Lower doses of ethanol $(0.5 \mathrm{~g} / \mathrm{kg})$ or morphine $(0.25 \mathrm{mg} / \mathrm{kg})$, or a shorter immobilization time (15 min) were ineffective. Ethanol, at an ineffective dose $(0.50 \mathrm{~g} / \mathrm{kg})$ enhanced both the effects of morphine and those of immobilization stress. The effects observed were antagonized by a per se ineffective dose of naloxone $(1.0 \mathrm{mg} / \mathrm{kg})$. The possibility that opiates may have a critical but modulatory effect on the actions of ethanol and/or immobilization is discussed.
\end{abstract}

A number of researches have studied, sometimes with contradictory results, the effects of ethanol administration in different animal species and their reversibility by naloxone (and naltrexone). It has been observed that, following administration of naloxone, or naltrexone in mice (Kiianmaa, Hoffman, \& Tabakoff, 1983), ethanol-induced excitatory effects are blocked in mice (Middaugh, Read, \& Boggan, 1977) and ethanol self-administration is decreased in monkeys (Altshuler, Phillips, \& Feinhandler, 1980). In addition, it has been demonstrated that naloxone reverses ethanol's effects on sexual behavior in hamsters (Nelson, Ostrowski, Noble, \& Reid, 1981) and ethanol-induced comas in humans (Jeffreys, Flanagan, \& Volans, 1980; Mackenzie, 1979; Sorensen \& Mattisson, 1978). On the other hand, naloxone did not influence the effects of ethanol on pain sensitivity, body temperature, sensorimotor performance, level of consciousness (Jorgensen \& Hole, 1981), or initial or acquired tolerance to ethanol in rats (Miceli, Marfaing-Jollat, \& Le Magnen, 1980).

Some investigations have finally shown the existence of memory impairment following ethanol administration in different animal species (see MacInnes \& Uphouse, 1973).

Recent experiments have demonstrated that opiates can affect memory in different animal species. Memory impairing or improving effects have been observed, particularly following morphine (or heroin) administrations, depending on animal strain or experimental conditions (Castellano, 1975, 1980; Martinez, Jensen, Messing, Rigter, \& McGaugh, 1981). Moreover, some research has found that ethanol exerts effects similar to those of morphine in mice, in vitro, and in humans (Jorgensen \& Hole, 1981).

Immobilization stress has recently been shown to exert strain-dependent effects on passive avoidance

The authors' mailing address is: Istituto di Psicobiologia e Psicofarmacologia, via Reno, 1-00198, Rome, Italy. behavior of mice (Castellano \& Puglisi-Allegra, 1983) and to enhance the effects of morphine in mice tested in this experimental condition (Castellano, Pavone, \& Puglisi-Allegra, 1983) and morphine-induced analgesia (Puglisi-Allegra \& Oliverio, 1983). Finally, a number of investigations have demonstrated the existence of an interaction of ethanol with stressors both in animals and in humans (for a review, see Pohorecky, 1981).

In the present research, the effects of posttrial ethanol administration were investigated in CD1 mice injected with morphine or subjected to immobilization stress, and tested in a passive avoidance apparatus. The naloxone reversibility of the effects observed was also assessed.

\section{METHOD}

\section{Subjects}

Male CD1 mice (River Labs, Como, Italy), weighing about $25 \mathrm{~g}$ at the beginning of the experiments were used throughout. Upon their arrival in the laboratory ( 2 weeks before the experiments), all mice were placed in cages in groups of eight. Food and water were available ad lib, and the mice were kept on a 12-h light/ 12-h dark cycle (7 a.m.-7 p.m.) at a constant temperature.

In all experiments, the animals were used once.

The test used and the experimental procedure were similar to those described by Castellano (1982). During training, each mouse was placed on a lighted platform, in front of which was a hole leading to a dark compartment with an electrified metallic grid floor. When the mouse stepped through the hole (off the platform) and onto the metallic grid, it immediately received an inescapable footshock $(0.7 \mathrm{~mA}, 50 \mathrm{~Hz})$ that lasted $1 \mathrm{sec}$. The mouse was then removed to its home cage to await testing. Test procedures were the same as training except that no shock was administered. The animals underwent a single learning trial.

Training and testing were performed between the hours of 2:00 and 5:00 p.m.

\section{Procedure}

In a first series of experiments, the effects of acute posttraining ethanol or morphine injections and of immobilization stress were investigated. 
For this purpose, six different groups of eight mice each were injected with ethanol $(0.5,1.0$, or $2.0 \mathrm{~g} / \mathrm{kg})$ or morphine $(0.25,0.5$, or $1.0 \mathrm{mg} / \mathrm{kg}$ ), and their performance was compared with that of saline-injected mice. Three other groups of eight mice each were subjected to immobilization stress $(15,30$, or $60 \mathrm{~min})$, and their performance was compared with that of nonimmobilized mice. All treatments were carried out immediately after training. Immobilization stress was produced by placing the animals in a snugly fitting Plexiglas restraining apparatus (Castellano \& Puglisi-Allegra, 1983) located in the room in which the passive avoidance experiments were run.

Three other groups of eight mice each were injected with ethanol $(2.0 \mathrm{~g} / \mathrm{kg})$ or morphine $(1.0 \mathrm{mg} / \mathrm{kg})$ or were subjected to immobilization stress $(60 \mathrm{~min}) 120 \mathrm{~min}$ after training. The performance of the first two groups was compared with that of mice injected with saline, and that of the third group was compared with that of nonimmobilized mice.

Finally, three groups of eight mice each did not receive footshock, but were injected immediately after training with ethanol $(2.0 \mathrm{~g} / \mathrm{kg})$ or morphine $(1.0 \mathrm{mg} / \mathrm{kg})$ or were immobilized for a 60 -min period. The performance of the first two groups was compared with that of saline-injected mice, and the performance of the third group, with that of nonimmobilized mice.

In a second series of experiments, the naloxone antagonism of the effects of ethanol, morphine, or immobilization stress were investigated.

For this purpose, six different groups of eight mice each were injected with saline (two injections), naloxone $(1.0 \mathrm{mg} / \mathrm{kg})$, ethanol $(2 \mathrm{~g} / \mathrm{kg})+$ saline or with morphine $(1.0 \mathrm{mg} / \mathrm{kg})+$ saline, or with ethanol + naloxone or morphine + naloxone combinations; other groups of eight mice each were injected with saline or naloxone $(1.0 \mathrm{mg} / \mathrm{kg})$ or were immobilized for $60 \mathrm{~min}$ following saline or naloxone injection. All treatments were carried out immediately after training.

In a third series of experiments, (1) the effects of ethanol on morphine or stressed mice, and (2) their antagonism by naloxone were investigated.

For this purpose, four different groups of eight mice each were injected with saline, ethanol $(0.5 \mathrm{~g} / \mathrm{kg})$, morphine $(0.5 \mathrm{mg} / \mathrm{kg})$, or an ethanol + morphine combination. Additional groups of mice $(\mathrm{n}=8)$ were injected with naloxone $(1.0 \mathrm{mg} / \mathrm{kg})$ or a naloxone + ethanol + morphine combination.

Finally, other groups of eight mice each were injected with saline or ethanol, or with ethanol, immediately after which they were immobilized (30 min). Also, additional groups of eight mice were injected with naloxone $(1 \mathrm{mg} / \mathrm{kg})$ or a naloxone + ethanol combination, immediately after which they were immobilized in the snugly fitting apparatus. All treatments were carried out immediately after training.

All experimental groups were tested in the apparatus $24 \mathrm{~h}$ after training. Ethanol concentration was adjusted with $.9 \%$ saline so that all animals received $1 \mathrm{ml}$ liquid per $10 \mathrm{~g}$ of mouse weight (MacInnes \& Uphouse, 1973). Morphine (HCl) (Carlo Erba, Milan, Italy) and naloxone (HCl) (ENDO, Garden City, N.Y.) were dissolved in $.9 \% \mathrm{NaCl}$ and injected ai a volume of $4 \mathrm{ml} / \mathrm{kg} . \mathrm{NaCl}$, $.9 \%,(4 \mathrm{ml} / \mathrm{kg})$ was used for control treatments. All injections were given intraperitoneally. The dose of naloxone was selected on the basis of previous experiments (Castellano, 1982; Castellano \& Puglisi-Allegra, 1983) and of preliminary work.

The results were statistically evaluated by an ANOVA (one- and two-way), in which (Castellano, 1982) the differences between the step-through latencies of the groups on the test and the training days were compared. Further analyses for individual betweengroups comparisons were carried out with post hoc tests (Duncan multiple range test).

\section{RESULTS}

\section{Experiment 1}

As compared with control groups, performance impairments were evident in mice injected with ethanol or morphine, as well as in mice that were immobilized immediately after training (Figure 1).

Separate ANOVAs (one-way), carried out for each experimental group (ethanol, morphine, and stress), showed significant differences between groups $[\mathrm{F}(3,28)$ $=86.80,67.44$, and 78.38, respectively, $\mathrm{p}<.01$ ].

Individual between-treatment comparisons showed significant differences between the performance of control groups and that of ethanol- $(1.0$ and $2.0 \mathrm{~g} / \mathrm{kg}$, but not $0.5 \mathrm{~g} / \mathrm{kg})$ and morphine- $(0.5$ and $1.0 \mathrm{mg} / \mathrm{kg}$, but not $0.25 \mathrm{mg} / \mathrm{kg}$ ) injected mice and of mice immobilized for 30 or $60 \mathrm{~min}$, but not $15 \mathrm{~min}(\mathrm{p}<.01)$.

No difference was found between the performance of mice injected with ethanol $(\mathrm{E} ; 2.0 \mathrm{~g} / \mathrm{kg}$ ) or morphine $(\mathrm{M} ; 1.0 \mathrm{mg} / \mathrm{kg})$ and mice that were immobilized (I; for $60 \mathrm{~min}$ ) $120 \mathrm{~min}$ after training and their corresponding control group (NI = nonimmobilized). [Retention scores (in seconds): saline $_{120}=95.0 \pm 5.0$, $\mathrm{E}_{120}=90.75 \pm 6.9, \mathrm{M}_{120}=97.25 \pm 6.4, \mathrm{NI}_{120}=94.75 \pm$ 5.0, $I_{120}=98.0 \pm 4.6$.] Finally, the mean step-through latencies of both the mice that had not received footshock but had been injected with saline or ethanol $(2.0 \mathrm{~g} / \mathrm{kg})$ or morphine $(1.0 \mathrm{mg} / \mathrm{kg})$ and those in the no-footshock nonimmobilized and immobilized (60 min) groups did not differ significantly from each other $24 \mathrm{~h}$ after training. [Retention scores (in seconds): saline $=2.6 \pm 0.5, \mathrm{E}=2.0 \pm 0.3, \mathrm{M}=1.8 \pm 0.1$, $\mathrm{NI}=2.6 \pm 0.8, \mathrm{I}=1.8 \pm 0.2$.]

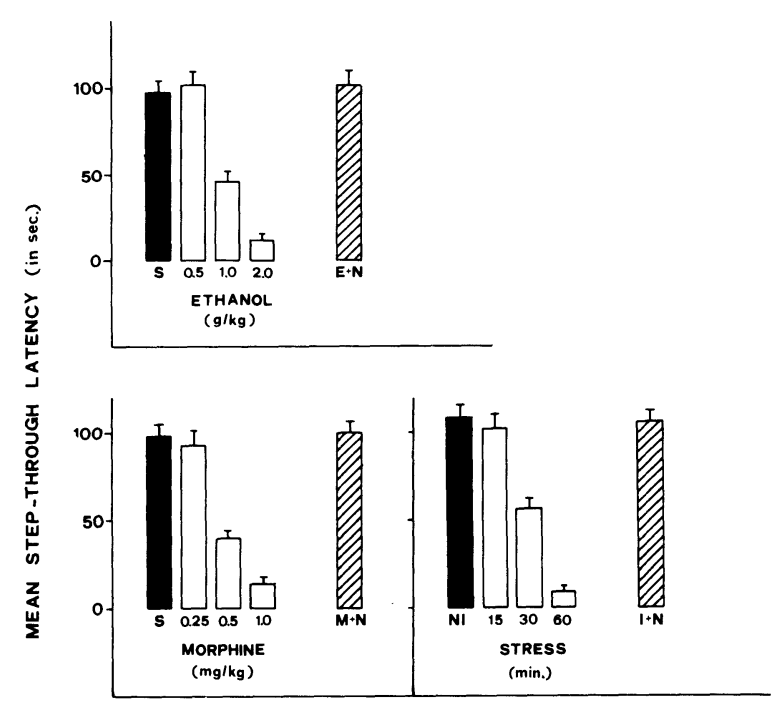

Figure 1. Mean step-through latencies $( \pm \mathrm{SEM})$ on test day. (a) Saline (S) injected or nonimmobilized (NI) mice (black columns); (b) mice injected with ethanol $(0.5,1.0$, or $2.0 \mathrm{~g} / \mathrm{kg}$ ) or morphine $(0.25,0.5$, or $1.0 \mathrm{mg} / \mathrm{kg})$ and mice immobilized for 15 , 30 , or $60 \mathrm{~min}$ (white columns); (c) ethanol (E; $2.0 \mathrm{~g} / \mathrm{kg}$ ) or morphine (M; $1.0 \mathrm{mg} / \mathrm{kg}$ ) or immobilized (I; $60 \mathrm{~min}$ ) mice injected with naloxone ( $\mathrm{N} ; 1.0 \mathrm{mg} / \mathrm{kg}$ ) (hatched columns). The treatments were carried out immediately after training in a passive avoidance apparatus. The mean step-through latencies on the training day ranged between $2.8 \pm 0.7$ and $3.2 \pm 1.3 \mathrm{sec}$. Maximum step-through latency on the test day $=136 \mathrm{sec}$. Groups of eight CD1 mice tested in the apparatus $24 \mathrm{~h}$ after training. 


\section{Experiment 2}

Naloxone, at a noneffective dose, antagonized the impairing effects exerted by ethanol $(2.0 \mathrm{~g} / \mathrm{kg})$ and morphine $(1.0 \mathrm{mg} / \mathrm{kg})$ administration and by $60 \mathrm{~min}$ of immobilization stress (Figure 1).

Separate ANOVAs (two-way), carried out for each experimental group (ethanol, morphine, and stress), showed significant main effects for both ethanol (or morphine or stress) and naloxone treatments $[\mathrm{Fs}(1,28)$ $=49.95$ and 42.54, 51.09 and 48.01, and 71.25 and 56.19 , respectively, $\mathrm{p}<.01$ ].

Significant ethanol (or morphine or stress) $\times$ naloxone interactions were also evident $[\mathrm{Fs}(1,28)=$ $46.55,47.74$, and 67.75 , respectively, $p<.01$ ]. Individual between-treatment comparisons showed significant differences between the performance of ethanol- (or morphine or stress) + naloxone-treated groups and that of ethanol- (or morphine or stress) treated groups $(p<.01)$.

The performance of both naloxone + ethanol (mean $=102.0 \pm 7.8 \mathrm{sec}$ ) or naloxone + morphine (mean $=100.37 \pm 6.9 \mathrm{sec})$ and naloxone + saline groups (mean $=100.12 \pm 8.7 \mathrm{sec}$ ) was not different from that of the saline- (two injections) treated groups $($ mean $=99.07 \pm 5.8 \mathrm{sec})$. The performance of naloxone-injected immobilized (mean $=105.25 \pm$ $5.7 \mathrm{sec}$ ) and that of naloxone-injected nonimmobilized mice $($ mean $=103.11 \pm 6.8 \mathrm{sec})$ was not significantly different from that of saline-injected nonimmobilized mice $($ mean $=98.37 \pm 4.4 \mathrm{sec})$.

\section{Experiment 3}

Ethanol, at a noneffective dose, enhanced both the effects of morphine and those of immobilization stress; these effects were reversed by the administration of naloxone (Tables 1 and 2).

Separate ANOVAs showed significant main effects for both ethanol $(0.5 \mathrm{~g} / \mathrm{kg})$ and morphine $(0.5 \mathrm{mg} / \mathrm{kg})$ treatments and ethanol $(0.5 \mathrm{~g} / \mathrm{kg})$ and stress $(30 \mathrm{~min})$ treatments $[\mathrm{Fs}(1,28)=4.16(\mathrm{p}<.05), 213.56(\mathrm{p}<.01)$, 44.98, $(\mathrm{p}<.01)$, and $484.20(\mathrm{p}<.01)$, respectively]. Significant ethanol $\times$ morphine and ethanol $\times$ stress interactions were also evident $[\mathrm{Fs}(1,28)=15.24$ and 15.65 , respectively, $p<.01$ ]. Individual between- treatment comparisons showed significant differences between: (1) the performance of ethanol + morphine (or ethanol + stress) groups and that of the ethanol- and saline-injected mice $(p<.01)$, and (2) the performance of ethanol + morphine (or ethanol + stress) groups and that of morphine or stressed mice $(p<.01)$. The performance of mice injected with morphine $(0.5 \mathrm{mg} / \mathrm{kg})$ and that of immobilized mice $(30 \mathrm{~min})$ was significantly different from that of their control groups $(p<.01)$.

When naloxone-injected groups are considered, separate ANOVAs (two-way) carried out for each experimental group showed significant main effects for both ethanol + morphine (or ethanol + stress) and naloxone treatments $[F s(1,28)=70.77$ and 72.62 , and 94.39 and 102.82 , respectively, $p<.01$ ]. Significant ethanol + morphine (or ethanol + stress) $\times$ naloxone interactions were also evident $[\operatorname{Fs}(1,28)=$ 44.12 and 110.50 , respectively, $\mathrm{p}<.01$ ].

Individual between-treatment comparisons showed significant differences between the performance of ethanol + morphine or ethanol + stress and that of the ethanol + morphine (or ethanol + stress), + naloxone groups $(p<.01)$. The performance of both mice injected with naloxone alone and mice injected with ethanol + morphine (or ethanol + stress) + naloxone was not significantly different from that of the control mice.

\section{DISCUSSION}

Two main points emerge from the results of the present research: (1) Posttrial administration of ethanol or morphine and posttrial immobilization stress exerted impairing effects on passive avoidance behavior in CS1 mice. In particular, these impairments were evident when the treatment was carried out immediately, but not $2 \mathrm{~h}$ after training in the apparatus, showing that they were due to posttrial effects; in addition, no effect was observed in the no-footshock groups, demonstrating a lack of proactive effects of the treatments on performance. (2) Ethanol administration enhanced the effects of both morphine and immobilization stress. In fact, the performance of

Table 1

Mean Step-Through Latencies on Test Day 24 Hours After Training, for Saline, Ethanol, Morphine, Ethanol + Morphine, and Ethanol + Morphine + Naloxone Injected Mice

\begin{tabular}{|c|c|c|c|c|c|c|c|}
\hline \multicolumn{6}{|c|}{ Treatments } & \multicolumn{2}{|c|}{ Latencies } \\
\hline & $\mathrm{mg} / \mathrm{kg}$ & & $\mathrm{mg} / \mathrm{kg}$ & & $\mathrm{mg} / \mathrm{kg}$ & Mean & SE \\
\hline Saline & & Saline & & Saline & & 92.87 & 6.7 \\
\hline Ethanol & 0.5 & Saline & & Saline & & 103.0 & 7.3 \\
\hline Morphine & 0.5 & Saline & & Saline & & 36.25 & 3.4 \\
\hline Naloxone & 1.0 & Saline & & Saline & & 105.25 & 6.4 \\
\hline Ethanol & 0.5 & Morphine & 0.5 & Saline & & 5.12 & 0.8 \\
\hline Ethanol & & Morphine & & Naloxone & 1.0 & 95.0 & 6.7 \\
\hline
\end{tabular}

Note-The mean step-through latencies on the training day ranged between: $2.6 \pm 0.9$ and $3.5 \pm 0.8$ sec. Maximum step-through latency on the test day was $130 \mathrm{sec}$. 
Table 2

Mean Step-Through Latencies on Test Day 24 Hours After Training, for Saline, Ethanol, and Naloxone Injected Mice and for Mice Immobilized and Mice Immobilized Following Ethanol or Ethanol + Naloxone Treatment

\begin{tabular}{|c|c|c|c|c|c|c|}
\hline \multicolumn{5}{|c|}{ Treatments } & \multicolumn{2}{|c|}{ Latencies } \\
\hline Minutes & & $\mathrm{mg} / \mathrm{kg}$ & & $\mathrm{mg} / \mathrm{kg}$ & Mean & SE \\
\hline Stress 0 & Saline & & Saline & & 99 & 3.1 \\
\hline Stress 0 & Ethanol & 0.5 & Saline & & 89.87 & 3.9 \\
\hline Stress 0 & Naloxone & 1.0 & Saline & & 97.25 & 4.8 \\
\hline Stress 30 & Saline & & Saline & & 42.12 & 4.2 \\
\hline Stress 30 & Ethanol & 0.5 & Saline & & 6.25 & 0.9 \\
\hline Stress 30 & Ethanol & 0.5 & Naloxone & 1.0 & 103.87 & 7.4 \\
\hline
\end{tabular}

Note-The mean step-through latencies on the training day ranged between $2.8 \pm 0.7$ and $3.4 \pm 0.5$ sec. Maximum step-through latency on the test day was $146 \mathrm{sec}$.

the morphine-injected (and the immobilized) mice was significantly lower following ethanol injection than that of the morphine (and of the immobilized) groups.

All the effects observed were antagonized by naloxone. With respect to ethanol, performance impairments following its administration have previously been demonstrated in different strains of mice (Baum, 1971; MacInnes \& Uphouse, 1973). MacInnes and Uphouse, in particular, have shown that intraperitoneal injections of ethanol, within the same dose range as that used in the present research, impair retention of passive avoidance conditioning in DBA/ $2 \mathrm{Jbg}$ and $\mathrm{C57BL} / 6 \mathrm{Jbg}$ mice and in their $\mathrm{F}_{1} \mathrm{C} 57 \times$ DBA hybrids.

Both behavioral impairment and behavioral improvement following posttrial morphine administration have been described, depending on animal strain, dose, and experimental condition (see Martinez et al., 1981). In particular, morphine has been shown to impair light-dark or pattern discrimination in DBA mice and to improve it in C57 mice (Castellano, 1975, 1980). The present research shows that the effects of morphine in CD1 mice are similar to those observed in DBA mice in different experimental conditions and similar to those observed in F344 rats in the same experimental conditions (see Messing, Jensen, Vasquez, Martinez, Spiehler, \& McGaugh, 1981).

With respect to immobilization stress, recent experiments (Castellano \& Puglisi-Allegra, 1983) have demonstrated that this type of stress exerts straindependent naloxone-reversible effects on passive avoidance behavior in mice. In particular, impairing effects have been evident in DBA and in Swiss mice, and improvements have been evident in C57 mice. The present results show that, in passive avoidance conditions, the effects of immobilization stress in CD1 mice, are similar to those evident in DBA and Swiss mice.

It must, moreover, be emphasized that the actions of ethanol and of morphine have been compared in a number of investigations. It has, for example, been shown that ethanol and morphine can exhibit similar effects (both decrease pain sensitivity, reduce body temperature, induce sleep, etc.; see Jorgensen \& Hole, 1981). In particular, cross-tolerance between ethanol and morphine has been reported with respect to the induction of hypothermia in rats (Khanna, Le, Kalant, \& LeBlanc, 1975) and inhibition of contractions in guinea pig preparation (Mayer, Khanna, Kalant, \& Spero, 1980). In addition, a number of studies have suggested the involvement of opioid peptides (and of some hormones, e.g., ACTH) in the defensive response of the organism to stress (Amir, Brown, \& Amit, 1980) and in its effects on passive avoidance behavior (Castellano \& Puglisi-Allegra, 1983). It has, moreover, recently been demonstrated that acute immobilization stress potentiates, in DBA mice, the effects of morphine administration on both passive avoidance and analgesia (Castellano et al., 1983; Puglisi-Allegra \& Oliverio, 1983). Finally, interaction of ethanol with stressors has also been reported. A low dose of ethanol has been found, for example, to antagonize the biochemical changes in blood generated by stress. In contrast, synergism between stressors and ethanol at the physiological level has been described. With respect to behavior, some studies have shown that stress can potentiate the depression induced by ethanol in both animals and humans (for a review, see Pohorecky, 1981).

All the effects observed in the present research were naloxone-reversible. It must be considered, on this point, that a number of investigations have demonstrated the naloxone reversibility of some of the effects of ethanol. It has, in particular, been reported that naloxone reverses ethanol's effects on sexual behavior in hamsters and ethanol-induced coma in humans, and decreases ethanol self-administration in monkeys (see Nelson et al., 1981; Kiianmaa et al., 1983). In addition, it has been demonstrated that naloxone antagonizes the potentiation of ethanolinduced sleep by $\beta$-endorphin (Luttinger, Frye, Nemeroff, \& Prange, 1983). Finally, recent experiments have suggested that ethanol may act at the enkephalinergic receptor level through condensation products, such as salsolinol (Lucchi, Bosio, Spano, 
\& Trabucchi, 1981), or through the formation of opiate-like compounds (such as tetrahydroisoquinolines, TIQS; see Nelson et al., 1981).

Further experiments will be necessary to identify the mechanisms underlying the effects observed in the present research and, in particular, to determine whether or not the treatments carried out influence memory processes. In fact, it must be recognized that many other factors could be involved. For example, the observed effects could be specific to passive avoidance and not show up in an active avoidance or an appetitively reinforced task. Further investigations, testing mice in a wider range of experimental conditions, will help to clarify this point.

The naloxone reversibility of the effects observed in the present research suggest the possible involvement of opiate receptors and an interaction of ethanol with the enkephalin or endorphin systems of the brain. However, it should also be recognized that naloxone may have nonopiate-related effects (Sawynok, Pinsky, \& LaBella, 1979). It must be finally stressed that opiates, if they are involved in the present effects, may have a critical, but modulatory, influence on the actions of ethanol and/or immobilization. It might be possible, for example, that ethanol might exert its effects by releasing a given substance, but only when a presynaptic opiate receptor has been activated.

In conclusion, while further experiments will be necessary to fully explain the present results, they show: (1) that the effects of ethanol on passive avoidance behavior in CD1 mice are naloxone reversible, and (2) that the negative influence exerted on this behavior by acute morphine administration, or immobilization stress, may be enhanced in subjects under ethanol effects.

\section{REFERENCES}

Altshuler, H. L., Phillips, P., \& Feinhander, D. A. Alteration of ethanol self-administration by naloxone. Life Sciences, 1980, 26, 679-680.

Amir, S., Brown, Z. W., \& Amit, Z. The role of endorphins in stress: Evidence and speculations. Neuroscience and Biobehavioral Reviews, 1980, 4, 77-86.

BAUM, M. Effect of alcohol on the resistance-to-extinction of an avoidance response: Replication in mice. Physiology \& Behavior, 1971, 6, 307-309.

Castellano, C. Effects of morphine and heroin on discrimination learning and consolidation in mice. Psychopharmacologia, $1975,42,235-242$.

Castellano, C. Dose-dependent effects of heroin on memory in two inbred strains of mice. Psychopharmacology, 1980, 67, 235239.

Castellano, C. Dose-dependent modulation of memory by the enkephalin analog FK 33-824 in C57BL/6 mice. Behavioral and Neural Biology, 1982, 36, 189-196.

Castellano, C., Pavone, F., \& Puglisi-Allegra, S. Morphine and memory in mice: Effects of stress and of prior experience. Behavioral Brain Research, 1983, in press.
Castellano, C., \& Puglisi-Allegra, S. Strain dependent modulation of memory by stress in mice. Behavioral and Neural Biology, 1983, 38, 133-137.

Jeffreys, B., Flanagan, R. J., \& Volans, G. N. Reversal of ethanol-induced coma with naloxone. Lancet $I, 1980,308-309$.

Jorgensen, H. A., \& HoLe, K. Does ethanol stimulate brain opiate receptors? Studies on receptor binding and naloxone inhibition of ethanol-induced effects. European Journal of Pharmacology, 1981, 75, 223-229.

Khanna, J. M., Le, A. D., Kalant, D. L., \& LeBlanc, A. E. Cross-tolerance between ethanol and morphine with respect to their hypothermic effects. European Journal of Pharmacology, 1975, 59, 145-151.

KilanmaA, K., Hoffman, P. L., \& Tabakoff, B. Antagonism of behavioral effects of ethanol by naltrexone in BALB/c, C57BL/6 and DBA/2 mice. Psychopharmacology, 1983, 79, 291-294.

Lucchi, L., Bosio, A., Spano, P. F., \& Trabucchi, M. Action of ethanol and salsolinol on opiate receptor function. Brain Research, 1981, 232, 506-510.

Luttinger, D., Frye, G. D., Nemeroff, C. B., \& Prange, A. J., JR. The effects of neurotensin, $\beta$-endorphin and bombesin on ethanol-induced behaviors in mice. Psychopharmacology, 1983, 79, 357-363.

MacInNes, J. W., \& Uphouse, L. L. Effects of alcohol on acquisition and retention of passive-avoidance conditioning in different mouse strains. Journal of Comparative and Physiologicai Psychology, 1973, 84, 398-402.

Mackenzie, A. J. Naloxone in ethanol intoxication. Lancet I, 1979, 733-734.

Martinez, J. L., Jensen, R. A., Messing, R. B., Rigter, H., \& McGaugh, J. L. (Eds.), Endogenous peptides and learning and memory processes. New York: Academic Press, 1981.

Mayer, J. M., Khanna, J. M., Kalant, H., \& Spero, L. Crosstolerance between ethanol and morphine in the guinea pig ileum longitudinal muscle/myenteric plexus preparation. European Journal of Pharmacology, 1980, 63, 223-232.

Messing, R. B., Jensen, R. A., Vasquez, B. J., Martinez, J. L., Spiehle R, V. R., \& McGaugh, J. L. Opiate modulation of memory. In J. L. Martinez, R. A. Jensen, R. B. Messing, H. Rigter, \& J. L. McGaugh (Eds.), Endogenous peptides and learning and memory processes. New York: Academic Press, 1981.

Miceli, D., Marfaing-Jollat, P., \& Le Magnen, J. Failure of naloxone to affect initial and acquired tolerance to ethanol in rats. European Journal of Pharmacology, 1980, 63, 327-332.

Middaugh, L. D., Read, E., \& Boggan, W. O. Effects of naloxone on ethanol induced alterations of locomotor activity in C57BL/6 mice. Pharmacology Biochemistry and Behavior, $1977,9,157-160$.

Nelson, J. L., Ostrowski, N. L., Noble, R. G., \& Reid, L. D. Naloxone reverses ethanol's effects on sexual behavior of the female Syrian hamster. Physiological Psychology, 1981, 9, 367-370.

Pohorecky, L. A. The interaction of alcohol and stress. Neuroscience and Biobehavioral Reviews, 1981, 5, 209-229.

Puglisi-Allegra, S., \& Oliverio, A. Social isolation: Effects on pain threshold and stress-induced analgesia. Pharmacology, Biochemistry and Behavior, 1983, 19, 679-681.

Sawynok, J., Pinsky, C., \& LaBella, F. S. On the specificity of naloxone as an opiate antagonist. Life Sciences, 1979, 25, 1621-1632.

Sorensen, S. C., \& Mattisson, K. Naloxone antagonist in severe alcohol intoxication. Lancet II, 1978, 668-669.

(Manuscript received June 3, 1983; revision accepted for publication October $2,1983$. ) 